\title{
Tümör Lizis Sendromunda Hemşirelik Yaklaşımı
}

\section{Nursing Approach in Tumor Lysis Syndrome}

\author{
Nazlı Öztürk ${ }^{1}$ (i) Fatma Arıkan ${ }^{1}$ \\ 1 Akdeniz Üniversitesi Hemşirelik Fakültesi, İç Hastalıkları Hemşireliği Anabilim Dalı, Antalya, TÜRKiYE \\ Geliş tarihi/ Date of receipt: 19/08/2020 Kabul tarihi/ Date of acceptance: 19/08/2020 \\ (c) Ordu University Faculty of Health Sciences, Department of Nursing, Turkey, Published online: 18/04/2021
}

\section{ÖZ}

Tümör lizis sendromu, hızlı hücre ölümünden kaynaklanan onkometabolik acil bir durumdur. Tümör lizis sendromu, tümör hedefli tedavinin bir sonucu olarak veya kendiliğinden ortaya çıkabilmektedir. Bu çalışmanın amacı tümör lizis sendromu ve hemşirelik bakımı ile ilgili literatür bilgisinin derlenmesidir. Tümör lizis sendromunun laboratuvar ve klinik belirti bulguları ile ilgili olarak kanser hastası yakından izlenmeli, yüksek risk grubundaki hastalara yeterli hidrasyon, fosfat bağlayıcıların kullanımı, ürik asit düşürücü tedavi ve hastanın potasyum alımının azaltılması gibi önleyici girişimlerin uygulanması önemlidir. Sağlık profesyoneli olan onkoloji ve yoğun bakım hemşireleri, hastanede yatan her kanser hastasını ve özellikle kemoterapi görenleri tümör lizis sendromu riski açısından sinıflandırarak kanser hastasına destekleyici bakım vermelidir.

Anahtar kelimeler: Tümör lizis sendromu, kanser, hemşirelik

\section{ABSTRACT}

Tumor lysis syndrome is an oncometabolic emergency caused by rapid cell death. Tumor lysis syndrome can occur spontaneously or as a result of tumor-targeted therapy. The aim of this study is to review the literature on Tumor Lysis Syndrome and nursing care.

The cancer patient should be closely monitored regarding the laboratory and clinical symptoms of tumor lysis syndrome, and preventive interventions such as adequate hydration, use of phosphate binders, uric acid-lowering treatment and reduction of the patient's potassium intake are important in high-risk patients. Oncology and intensive care nurses, who are health professionals, should classify each hospitalized cancer patient and especially those receiving chemotherapy in terms of tumor lysis syndrome risk and provide supportive care to the cancer patient.

Key words: Tumor lysis syndrome, cancer, nursing

ORCID IDs of the authors: NÖ:0000-0003-2108-0735; FA:0000-0003-0481-1903

Sorumlu yazar/Corresponding author: Arş. Gör. Nazlı Öztürk

Akdeniz Üniversitesi Hemşirelik Fakültesi, İç Hastalıkları Hemşireliği Anabilim Dalı, Antalya, TÜRKİYE

e-posta/e-mail: ozturknaz@outlook.com

Atıf/Citation: Öztürk N, Arıkan F. (2021). Tümör Lizis Sendromunda Hemşirelik Yaklaşımı. Ordu Üniversitesi Hemşirelik Çalışmaları Dergisi, 4(1),115-122. DOI:10.38108/ouhcd.782461 


\section{Giriş}

Tümör Lizis Sendromu (TLS), çok sayıda hızla bölünen malign tümör hücreleri öldürüldüğünde (veya parçalandığında), elektrolitler de dahil olmak üzere hücre içi bileşenlerin büyük miktarda sistemik dolaşıma salındığında meydana gelen bir sendromdur. İyi yönetilmediğinde elektrolit dengesizlikleri, akut böbrek hasarı, asit-baz dengesizlikleri ve ölüm gibi potansiyel olarak yaşamı tehdit eden komplikasyonlar oluşturabilmektedir (Kaplow ve Iyere, 2016). TLS insidansı oldukça değişkendir ve sıklığı malignite tipine göre değişmektedir (Hüzmeli, 2019). TLS ile ilişkili en yaygın maligniteler arasında non-Hodgkin lenfoma (\% 30), katı tümörler (\% 20), akut miyeloid lösemi (\% 19) ve akut lenfositik lösemi (\% 13) yer almaktadır (Adeyinka ve Bashir, 2019). TLS insidansını arttırabilen yüksek proliferasyon hızına sahip tümörler, kemoterapiye duyarlılığı yüksek olan tümörler, böbrek hastalığı öyküsü gibi doğal risk faktörleri bulunmaktadır (Adeyinka ve Bashir, 2019; Hüzmeli, 2019). Bu çalışmanın amacı TLS' de hemşirelik yaklaşımını incelemektir. Özellikle siv1 elektrolit dengesizliklerinin ön planda olduğu bu sendromun yönetiminde sağlık profesyoneli olan hemşireler anahtar rol oynamaktadır. Bu kapsamda; TLS'nin patofizyolojisi, risk faktörleri ve sinıflamas1, belirti ve bulgular1, tan1, tedavi ve hemşirelik bakımı konusunda bilgiler verilmiştir

\section{Patofizyolojisi}

TLS temelinde hücrelerin ve kanser hücrelerinin potasyum, fosfor ve ürik asit açısından zengin olmasından kaynaklanmaktadır (Darmon, Guichard, Vincent, Schlemmer ve Azoulay, 2010). Kanser hücrelerinin kemoterapi, embolizasyon veya radyasyon tedavisi olmaksızın ölmesi ile ya da kanser hedefli tedaviye sekonder gelişebilmektedir (Darmon, Guichard, Vincent, Schlemmer ve Azoulay, 2010; Mirrakhimov, Voore, Khan ve Ali, 2015). Her iki durumda da bahsedilen hücre içi maddelerin salınımı, TLS'nin patobiyolojisine ve komplikasyonlarına aracılık etmektedir

(Mirrakhimov, Voore, Khan ve Ali, 2015).

Hiperürisemi: Hiperürisemi, hiperfosfatemi ile birlikte akut böbrek hasarına yol açabilen TLS'nin en ayırt edici özelliğidir (Edeani ve Shirali, 2016). Seruma salınan pürin içeren nükleik asitler (adenozin ve guanin) ürik aside katabolize edilir ve fazla miktarda ise ürik asit atılımı için renal tübüler kapasiteyi aşar (Sarno, 2013). Katabolik yolda, nükleik asitler ilk olarak hipoksantin ve ksantine metabolize olurlar ve bunlar daha sonra ksantin oksidazın enzimatik etkisiyle ürik aside dönüștürülür (Sarno, 2013; Edeani ve Shirali, 2016). Ürik asit suda çok az çözünür dolayısıyla distal ve toplayıcı tübüllerin fizyolojik olarak asit ortamında çözünürlüğü önemli ölçüde azalır (Edeani ve Shirali, 2016; Williams ve Killeen, 2019). Ürik asit kristalleri renal dolaşımda yoğunlaştığında kolayca çökelmeye başlayarak; böbrekte tübül tıkanması, obstrüktif üropati, glomerüler filtrasyon ve idrar çıkışında azalmayla sonuçlanır (Williams ve Killeen, 2019). Ürik asit kristalleri obstrüksiyona neden olarak renal hasara katkıda bulunmasına ek olarak monosit kemoatraktan protein-1 (MCP-1) ve makrofaj göçü inhibisyon faktörü (MIF) arac1lı inflamatuar yanıt klinik tablonun ağırlaşmasına yol açmaktadır (Edeani ve Shirali, 2016).

Hiperkalemi: Potasyum renal at1lım yoluyla düzenlenen hücre içi bir elektrolittir ve hiperkalemi, kardiyak disritmilere ve ani ölüme yol açabilen bir durumdur (Strauss, Hamlin ve Dang, 2017). Kalsiyum, potasyumun kardiyomiyositlerin dinlenim membran potansiyeli üzerindeki etkilerini doğrudan bloke ederek kadiyak membranın stabilize edilmesine yardımc1 olur (Wilson ve Berns, 2014). Böylece hipokalsemi, hiperkalemiye bağl1 kardiyotoksisiteyi ve kardiyak disritmileri şiddetlendirir (Wilson ve Berns, 2014; Strauss, Hamlin ve Dang, 2017). Masif tümör hücresi lizizi, potasyumu ekstraselüler ortama salar ve özellikle renal hasar durumunda kas ve karaciğer tarafından alım kapasitesi aşıldığında ciddi hiperkalemiye yol açar (Strauss, Hamlin ve Dang, 2017).

Hiperfosfatemi ve Hipokalsemi: Tümör hücreleri genellikle normal hücrelere göre daha yüksek konsantrasyonlarda fosfat içerir ve salınan fosfat miktarı tümör tipine göre değişir (Mirrakhimov, Voore, Khan ve Ali, 2015). Masif tümör lizisinde, fosfatın renal tübüler atılım mekanizmaları doymuş hale gelir (Zafrani, Canet ve Darmon, 2019). Fazla serum fosfat kalsiyuma bağlanır ve tüm vücutta sekonder hipokalsemi ve kalsiyum fosfat birikimi ile sonuçlanır (Mirrakhimov, Voore, Khan ve Ali, 2015; Zafrani, Canet ve Darmon, 2019). Hipokalsemi asemptomatikten yaşamı tehdit eden kalp iletim anormalliklerine kadar değişebilir veya kalpte kalsiyum fosfat birikimi ölümcül disritmilere neden olabilir (Mirrakhimov, Voore, Khan ve Ali, 2015). Nefrokalsinoz, renal tübüllerdeki kalsiyum fosfat kristallerinin çökelmesi olarak tanımlanmaktadır ve bu nefrolitiazise neden olup obstrüktif üropati gelişmesine yol açabilmektedir (Mirrakhimov, Voore, Khan ve Ali, 2015; Zafrani, Canet ve Darmon, 2019). 


\section{Risk Faktörleri ve Sınıflaması}

Laboratuvar ve klinik tümör lizis sendromunun gelişmesi için iyi bilinen bir dizi risk faktörü mevcuttur ve s1kl1kla anti-kanser terapisi ile hızlandırılan hücresel bozulmanın hacmi ve hızı ile ilgilidir (Jones, Will, Jackson, Webb ve Rule, 2015). Hematolojik veya solid tümörü olan hastalar arasında, sitoredüktif tedaviye oldukça duyarlı olan tümörler en büyük TLS riskini oluşturmaktadır (Williams ve Killeen, 2019). Genel olarak; TLS için risk faktörleri; hasta ile ilişkili, hastalıkla ilişkili ve tedaviyle ilişkili olmak üzere üç grupta siniflandirilabilmektedir (Jones, Will, Jackson, Webb ve Rule, 2015) (Tablo 1). Buna ek olarak Cairo-Bishop Klinik TLS'nin Evrelendirmesi Tablo 2'de yer almaktadır.

\section{Klinik Belirti ve Bulgular}

TLS'nin klinik görünümü spesifik değildir ve hiperkalemi, hiperfosfatemi, sekonder

hipokalsemi ve hiperürisemi ile ilişkili metabolik komplikasyonlarını yansitır (Cairo ve Bishop, 2004). Klinik belirtiler arasında zayıflık, iştahsızlık, bulant1, kusma ve diyarenin yan1 sira kardiyovasküler ve nöromüsküler anormallikler bulunur (Tablo 3).

\section{Tanıs}

Cairo ve Bishop'un 2004 yılında yayınladıkları rehberde laboratuvar ve klinik TLS tanımlanmıştır (Cairo ve Bishop, 2004) (Tablo 4).

\section{Tıbbi Yönetimi}

Analit izlemi: Sitoredüktif tedaviye başlamadan veya hipoürisemik ajanların uygulanmasından önce temel analit değerlerinin elde edilmesi önemlidir (Strauss, Hamlin ve Dang, 2017). Analit testinin sıklığı, TLS risk değerlendirmesine dayanmaktadır (Williams ve Killeen, 2019). TLS tanısı konmuş ya da yüksek risk grubunda olan hastaların 4-6 saatte bir; TLS için orta risk grubunda olan hastaların ise 6-8 saatte bir ürik asit, elektrolit, Laktat dehidrogenaz (LDH) ve kreatinin takibi yapılması önemlidir (Strauss, Hamlin ve Dang, 2017; Williams ve Killeen, 2019). Rasburikaz alan hastalar için, laboratuvarlar, hızlı in vitro ürik asit parçalanmasını önlemek amaçlı cihazda hemen çalıştırılmak üzere, derhal buz üzerine yerleştirilen ve buz üzerinde tutulan önceden soğutulmuş tüplerde ürik asit örnekleri toplamak için protokoller geliştirmelidir (Williams ve Killeen, 2019).

Hidrasyon: TLS'yi yönetmenin ilk adımı, hidrasyon ve sıv1 dengesinin dikkatli bir şekilde izlenmesiyle yüksek idrar çıkışı sağlamaktır (Criscuolo, Fianchi, Dragonetti ve Pagano, 2015).
Amaç böbrek tübüllerinde ürik asit kristalleşmesini ve kalsiyum fosfat birikimini önlemektir (Strauss, Hamlin ve Dang, 2017). Yetişkinlerde hidrasyonun; idrar çıkışı 24 saatte 3 1/m2 olacak şekilde planlanması önerilmektedir (Jones, Will, Jackson, Webb ve Rule, 2015). Hidrasyon sivisina potasyum eklenmemesi, dengeli veya izotonik solüsyonlar tercih edilmesi önemlidir (Criscuolo, Fianchi, Dragonetti ve Pagano, 2015). Saatlik idrar ve alt saatte bir aldığ 1 çıkardığ 1 sıvı takibi yapılmalıdır (Jones, Will, Jackson, Webb ve Rule, 2015). Kusma veya ishal gibi tüm sıvı kayıpları kaydedilmelidir (Strauss, Hamlin ve Dang, 2017; Jones, Will, Jackson, Webb ve Rule, 2015). Bebekler, yaşlılar, kalp ve böbrek hastalığı öyküsü olan hastalar özellikle aşırı sıvı yüklenmesi riski altındadır (Wilson ve Berns, 2014). İdrar çıkışında bir azalma, sıv1 dengesinin ve laboratuvar parametrelerinin yeniden değerlendirilmesini gerektirmektedir (Dubbs, 2018). Altta yatan hastalığa bağlı olarak, acil müdahale gerektirebilecek tümör tarafından idrar akışına fiziksel bir engel olup olmadığını değerlendirmek önemlidir (Dubbs, 2018; Wilson ve Berns, 2014). İdrar çıkışında azalma durumunda diüretik kullanırken dikkatli olunmalıdır. $0.5 \mathrm{mg} /$ $\mathrm{kg}$ intravenöz (IV) furosemid yararlı bir acil tedavi olabilirken, ilaç tübüler ürik asit birikimini arttırarak renal tübüler blokaj varlığında daha az etkili olabilmektedir (Jones, Will, Jackson, Webb ve Rule, 2015; Strauss, Hamlin ve Dang, 2017).

Hiperürisemi: Allopurinol, renal tübüllerde ürik asit kristallerinin gelişimini engelleyerek etki gösteren bir ksantin oksidaz inhibitörüdür, ancak birikmiş ürik asidin parçalanmasını etkilemez (Williams ve Killeen, 2019). Bu nedenle, allopurinol profilaktik ortamda yararlı olmakla birlikte, yerleşik TLS'de tercih edilen ilaç değildir (Zafrani, Canet ve Darmon, 2019). Allopurinolün aksine, rasburikaz-rekombinant bir ürat oksidazüratı doğrudan daha çözünür bileşik allantoine metabolize eder (Williams ve Killeen, 2019). Bu nedenle rasburikaz ürik asit birikintilerini parçalayabilir ve ürat düzeylerini allopurinolden önemli ölçüde daha hızlı azaltabilmektedir (Williams ve Killeen, 2019; Zafrani, Canet ve Darmon, 2019).

Hiperfosfatemi ve Hipokalsemi: Rasburikazın hidrasyonu ve zamanında uygulanması önemli hiperfosfatemiyi engellemiyorsa, diyaliz dışında fosfat seviyelerini kontrol etmek zor olabilmektedir (Mirrakhimov, Voore, Khan ve Ali, 2015) 
Tablo 2. Cairo-Bishop Klinik TLS'nin Evrelendirmesi

\begin{tabular}{|c|c|c|}
\hline Hasta ile İlişkili Faktörler & Hastalıkla İlişkili Faktörler & Tedaviyle İlișkili Faktörler \\
\hline $\begin{array}{ll}\text { - } & \text { Dehidratasyon } \\
\text { - } & \text { Oligüri ya da anüri } \\
\text { - } & \text { Renal disfonksiyon } \\
\text { - } & \text { Yaygositoz lenf nodu tutulumu } \\
\text { - } & \text { Hiperkalemi } \\
\text { - } & \text { Hiperfosfatemi } \\
\text { - } & \text { Yüksek tümör yükü } \\
\text { - } & \text { Serum lakrisemi } \\
& \text { yüksekliği dehidrogenaz } \\
\text { - } & \text { Nefrotoksik ajanlar }\end{array}$ & $\begin{array}{l}\text { Yüksek tümör yükü ya da hizla } \\
\text { bölünen hücrelere sahip tümör } \\
\text { - Burkitt lenfoma } \\
\text { - Akut lenfoblastik lösemi } \\
\text { - Akut lenfoblastik lösemi } \\
\text { - Kronik lösemi } \\
\text { - Meme kanseri } \\
\text { - T hücreli lenfoma } \\
\text { - Kenfosarkoma } \\
\text { - Küçük hücreli akciğer } \\
\text { - Mide kanseri } \\
\text { - Kolorektal kanser } \\
\text { - Germ hücreli kanser } \\
\text { - Over kanseri } \\
\text { - Tulvar kanser } \\
\text { - Nimoma } \\
\text { - Möroblastom } \\
\text { - Metastatik lenfoma } \\
\text { Metastatik medullablastom }\end{array}$ & $\begin{array}{ll}\text { - } & \text { Kortikosteroidler } \\
\text { - } & \text { Intratekal metotreksat } \\
\text { - } & \text { Tamoksifen } \\
\text { - } & \text { Gemtüksimab } \\
\text { - } & \text { Alemtuzumab } \\
\text { - } & \text { Kladribin } \\
\text { - İmatinib mesilat } \\
\text { - } & \text { Sitarabin } \\
\text { - } & \text { Etoposid } \\
\text { - } & \text { Sispilatin } \\
\text { - } & \text { Doksorubisin } \\
\text { - } & \text { Paklitaksel } \\
\text { - } & \text { Fludarabin }\end{array}$ \\
\hline
\end{tabular}

Tablo 2. Cairo-Bishop Klinik TLS'nin Evrelendirmesi

\begin{tabular}{|c|c|c|c|c|c|c|}
\hline & Grade 0 & Grade I & Grade II & Grade III & Grade IV & Grade V \\
\hline Kreatinin & Yok & $\begin{array}{l}\text { Normalin } 1.5 \text { katı } \\
\text { Kreatinindeki artış } \\
\text { kemoterapötik } \\
\text { ajana bağlı değildir. } \\
\text { Müdahale } \\
\text { endikasyonu yok }\end{array}$ & $\begin{array}{l}\text { Normalin >1.5-3 katı } \\
\text { Kreatinindeki artış } \\
\text { kemoterapötik } \\
\text { bağlı değildir. }\end{array}$ & $\begin{array}{l}\text { Normalin >3-6 katı } \\
\text { Kreatinindeki artış } \\
\text { kemoterapötik } \\
\text { ajana bağlı değildir. }\end{array}$ & $\begin{array}{l}\text { Normalin }>6 \text { katı } \\
\text { Kreatinindeki artış } \\
\text { kemoterapötik } \\
\text { ajana bağlı değildir. }\end{array}$ & Ölüm \\
\hline $\begin{array}{l}\text { Kardiyak } \\
\text { aritmi }\end{array}$ & Yok & - & $\begin{array}{l}\text { Acil olmayan tibbi } \\
\text { müdahale gereklidir } \\
\text { Kemoterapötik ajana } \\
\text { bağlı olmayan kardiyak } \\
\text { aritmiler. }\end{array}$ & $\begin{array}{l}\text { Semptomatik ve } \\
\text { tıbi müdahale ile } \\
\text { kontrol edilen ve } \\
\text { kemoterapik } \\
\text { ajanlara bağlı } \\
\text { olmayan aritmiler }\end{array}$ & $\begin{array}{l}\text { Yaşamı tehdit edici } \\
\text { (örneğin, KY ile } \\
\text { ilişkili aritmi, } \\
\text { hipotansiyon, } \\
\text { senkop, şok). }\end{array}$ & Ölüm \\
\hline Nöbet & Yok & - & $\begin{array}{l}\text { Kısa, generalize nöbet; } \\
\text { Antikonvülsanlar } \\
\text { tarafindan iyi kontrol } \\
\text { edilen nöbet (ler) veya } \\
\text { günlük yaşam } \\
\text { aktivitelerine } \\
\text { etkilemeyen seyrek } \\
\text { fokal motor nöbetler }\end{array}$ & $\begin{array}{l}\text { Bilinç } \\
\text { değişikliğ̆inin } \\
\text { yaşandığ1 tıbbi } \\
\text { müdahaleye } \\
\text { rağmen gelişen } \\
\text { nöbetler }\end{array}$ & $\begin{array}{l}\text { Uzun süreli, } \\
\text { tekrarlayan veya } \\
\text { kontrolü zor olan } \\
\text { her türlü nöbet (örn. } \\
\text { Status epileptikus, } \\
\text { inatç1 epilepsi). }\end{array}$ & Ölüm \\
\hline
\end{tabular}


Tablo 3. TLS Belirti ve Bulguları

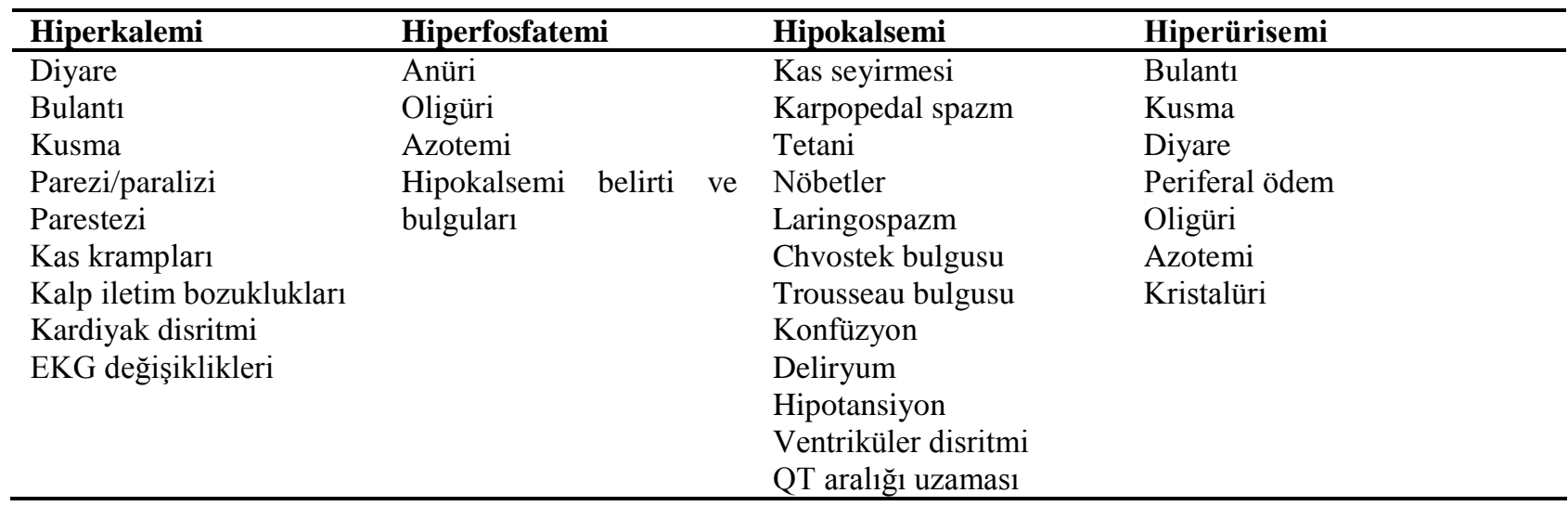

Tablo 4. TLS Laboratuvar ve Klinik Tanısı

\begin{tabular}{|c|c|}
\hline Laboratuvar TLS* & Klinik TLS \\
\hline $\begin{array}{l}\text { - Ürik asit } \geq 8 \mathrm{mg} / \mathrm{dl} \text { veya başlangıca göre\% } 25 \\
\text { artış } \\
\text { - } \quad \text { Potasyum } \geq 6.0 \mathrm{mEq} / \mathrm{L} \text { veya başlangıca göre\% } \\
25 \text { artış } \\
\text { - } \quad \text { Fosfat } \geq 4.5 \mathrm{mg} / \mathrm{dl} \text { veya başlangıca göre } \% 25 \\
\text { artış } \\
\text { - Calcium } \leq 7 \mathrm{mg} / \mathrm{dL} \text { veya başlangıca göre } \% 25 \\
\text { azalma } \\
\text { *Kanserli veya kanser tedavisi gören bir hastada, } \\
\text { tedavinin başlamasından önceki } 3 \text { gün ve sonraki } \\
7 \text { güne kadar belirtilen anormalliklerden iki veya } \\
\text { daha fazlasinın varlığ durumunda laboratuvar } \\
\text { TLS tanısı konmaktadır. }\end{array}$ & $\begin{array}{l}\text { Laboratuvar TLS'li bir hasta ve aşağıdakilerden en az bir } \\
\text { tanesi en az biri } \\
\text { - Kreatinin } \geq 1.5 \text { X Normal Üst Limit (yaş>12 yıl } \\
\text { - } \text { veya yaşa göre ayarlanmış) } \\
\text { - Ani ölüm } \\
\text { - Nöbet }\end{array}$ \\
\hline
\end{tabular}

Asemptomatik hipokalsemi tedavi edilmemelidir, çünkü tedavi böbreklerde kalsiyum fosfat birikimini daha da hızlandırabilmektedir (Zafrani, Canet ve Darmon, 2019; Mirrakhimov, Voore, Khan ve Ali, 2015). Kalsiyum düzeyinin normalin altına düşmesi durumunda kardiyak izlem önerilmektedir (Williams ve Killeen, 2019). TLS'de gelişen hipokalsemide amaç semptomları tedavi etmektir ancak biyokimyasal parametreleri referans aralıklarına döndürmemek gerekmektedir (Jones, Will, Jackson, Webb ve Rule, 2015).

Hiperkalemi: Potasyum $\geq 6.0 \mathrm{mEq} / \mathrm{L}$ veya başlangıca göre $\% 25$ artış olması durumunda kardiyak izlem yapılması gereklidir (Puri, Sharma, Gunturu ve Ahmed, 2020). Potasyum düzeyinin $\geq 7.0 \mathrm{mEq} / \mathrm{L}$ 'nin üzerine çıkması durumunda hastanın diyalize alınması gerekmektedir (Jones, Will, Jackson, Webb ve Rule, 2015). Potasyum düzeylerini düşürmek için standart önlemler alınabilir ancak etkileri geçicidir ve sıklıkla diyaliz gerekmektedir (Alakel, Middeke, Schetelig ve Bornhouser, 2017). Akut kardiyotoksisite olmas1 durumunda sürekli kardiyak izlem ile k1sa bir kalsiyum glukonat infüzyonu ile tedavi edilmelidir(Jones, Will, Jackson, Webb ve Rule, 2015; Alakel, Middeke, Schetelig ve Bornhouser, 2017; Puri, Sharma, Gunturu ve Ahmed, 2020). Nebulize veya intravenöz salbutamol, intravenöz insülin ve glukoz infüzyonu etkili olabilmektedir (Belay, Yirdaw ve Enawgaw, 2017). Her iki strateji de potasyumun ekstraselüler alandan hücre içi boşluğa hareketini arttırır (Jones, Will, Jackson, Webb ve Rule, 2015; Belay, Yirdaw ve Enawgaw, 2017).

Renal diyaliz: Ürat oksidaz tedavisinin kullanımı, TLS riski olan hastalarda diyaliz ihtiyacını azaltmıştır (Mirrakhimov, Voore, Khan ve Ali, 2015). Bununla birlikte uygun profilaktik 
önlemler alınmasına rağmen renal bozulma önlenemediğinde ve önemli miktarda sıv1 yüklenmesi, hiperkalemi, hiperürisemi, hiperfosfatemi veya hipokalsemi geliștiğinde, böbrek diyalizi endikedir (Alakel, Middeke, Schetelig ve Bornhouser, 2017). Periton diyalizi daha yavaş bir klinik iyileşme sağladığı için önerilmemektedir (Garimella ve ark., 2016; Alakel, Middeke, Schetelig ve Bornhouser, 2017). Literatürde TLS'de metabolitlerin kana sürekli salınımı göz önüne alındığında günlük diyalizin en iyi strateji olabileceğini belirten çalışmalar mevcuttur (Mirrakhimov, Voore, Khan ve Ali, 2015; Alakel, Middeke, Schetelig ve Bornhouser, 2017). Böbrek fonksiyonlarında ve idrar çıkışında yeterli iyileşme sağlanana kadar diyalize devam edilmelidir (Garimella ve ark., 2016).

\section{Hemșirelik Bakımı}

TLS, hayat1 tehdit eden onkolojik bir acil durumdur ve onkolog, nefrolog, dahiliye uzman1, yoğun bakım uzmanı, yoğun bakım hemşireleri ve onkoloji hemşirelerini içeren disiplinler arası bir ekip tarafından yönetilir (Taho-Tammy ve Winokur, 2019). Kanser hastalarının hayatını tehdit eden bir durum olması nedeniyle, TLS gelişme riski yüksek olan hastaların belirlenmesi ve erken proflaktik tedaviye başlanması zorunludur (Taho-Tammy ve Winokur, 2019; Adeyinka ve Bashir, 2019). TLS gelişme riski yüksek hastalarda öncelikle TLS gelişimini önleme, sıv1 elektrolit dengesini sağlamak için beslenme ve boşaltıma yönelik uygulamalar, TLS gelişmiş hastalarda ise komplikasyonları önleme hemșirelik bakımı kapsamında yer almaktadır. Yoğun bakım ve onkoloji hemşireleri bu sendromun yönetiminde anahtar rol oynamaktadır (Adeyinka ve Bashir, 2019). TLS'li hastanın hemşirelik bakımının planlanmasında ele alınabilecek hemşirelik tanıları ve hemşirelik tanılarına yönelik girişimler Tablo 5'de verilmiştir (Özen ve Enç, 2013; Sleutel, Brown ve Wells, 2016; Kaplow ve Iyere, 2016).

\section{Önleme}

Kemoterapi alan kanserli hastalara yönelik bakım hedefleri arasında TLS için yüksek riskli hastaların belirlenmesi, önleyici tedavilerin başlatılması; metabolik ve renal komplikasyonların ekip işbirliği ile yönetilmesi ve hasta ve ailesine destekleyici bakım sağlamak yer almaktadır (Sleutel, Brown ve Wells, 2016). TLS'yi önlemek ve tedavi etmek için kemoterapi gören hastalar başlangıçta risk faktörleri açısından değerlendirilmeli, tedavinin başlatılması sırasında ve sonrasında yakından takip edilmelidir (Kaplow ve Iyere, 2016). Önleyici bakımın temelinde hidrasyon, allopurinol ve rasburikaz yer alır ve bunların hastaya hekim önerisi doğrultusunda düzenli şekilde uygulanması sağlanmalıdır (HeldWarmkessel, 2010).

\section{Beslenme}

TLS'li hastalarda potasyum ve fosfordan kisitlı bir diyet alınması önemlidir. Hasta ve yakınlarına potasyum (portakal, muz, domates, çikolata) ve fosfordan (süt, et, peynir, yumurta, balık ve karbonatlı içecekler) zengin besin grupları ile ilgili eğitim verilir (Brown C.G., 2015).

\section{Boşaltım}

İntravenöz hidrasyon mümkün olan en k1sa sürede, ideal olarak kemoterapiye başlamadan 2 gün önce, kemoterapi sırasında ve sonrasında 2-3 gün devam etmelidir. Parenteral olarak önerilen günlük sıv1 miktar1 $3.000 \mathrm{ml} / \mathrm{m} 2$ 'dir. Hidrasyonun sağlanmasıyla; yüksek idrar çıkışı sağlanarak (100 $\mathrm{ml} / \mathrm{m} 2$ 'nin üzerinde her saat), kalsiyum fosfat çökeltisi riski azaltılmaktadır (Held-Warmkessel, 2010; Kaplow ve Iyere, 2016).

Kanser hastas1; periferik ödem, boyunda venöz dolgunluk, kilo alımı ve pulmoner ödem gibi sıv1 yüklenmesi ve azalmış turgor, susuzluk ve kilo kaybı gibi dehidratasyon belirti ve bulguları yönünden takip edilmelidir (Taho-Tammy ve Winokur, 2019; Held-Warmkessel, 2010). Böbrek fonksiyonlarını izlemek için serum kreatinin, Blood Urea Nitrogen (BUN) seviyeleri, kalsiyum, fosfat, potasyum ve ürik asit düzeyleri de dahil olmak laboratuvar sonuçları ile birlikte aldığı çıkardığı sıv1, günlük kilo değișimi değerlendirilmelidir (Sarno, 2013). Dehidratasyonu ve renal obstrüksiyonu bulunan hastalarda diüretik kullanımından kaçınılmalıdır (Held-Warmkessel, 2010; Sarno, 2013)

Optimal olarak, kemoterapiye başlamadan 1-2 gün önce hastaya allopurinol başlanması gereklidir. Allopurinol alan kanser hastasi alerjik reaksiyon (deri döküntüsü, ateş, titreme, bulantı, kusma, eozinofil sayısında artış) ve diğer yan etkiler açısından gözlenmelidir (Beth McGraw, 2008). Allopurinol tedavisi, aşırı ürik asidi önlemeye yardımcı olduğu için kemoterapiden önce başlatılır, ancak halihazırda hiperürisemisi olan hastalarda ürik asit düzeylerini düşürmez (Beth McGraw, 2008; Held-Warmkessel, 2010). Buna ek olarak, yüksek doz metotreksat, siklofosfamid, merkaptopürin ve azatioprin gibi kanseri tedavi etmek için kullanılan diğer ilaçların atılımını engeller ve kapesitabinin etkinliğini azaltır (HeldWarmkessel, 2010). 
Allopurinolün aksine rasburikaz, hiperürisemiyi tedavi eden bir ilaçtır. Intravenöz verilen, rasburikaz ürik asidi, idrarda ürik asitten çok daha fazla çözünür olan allantoine dönüştürür (Mackiewicz, 2012).

Tablo 5. TLS'de Hemşirelik Bakımı

Hemşirelik Tanısı 1. Spontan ya da antikanser
tedaviye yanıt olarak tümör hücrelerinin lizisine
sekonder serum potasyum düzeyinin yükselmesine
bağlı Hiperkalemi

Amaç: Hastada serum potasyum düzeyinin normal aralıklarda olması

Hemşirelik Girişimleri:

- Hastanın yaşamsal bulguları takip edilir.

- Hasta hiperkalemi belirti ve bulguları (diyare, mide bulantis1, kusma, disritmi, EKG değişiklikleri) yönünden takip edilir.

- Hastanın serum potasyum değeri düzenli aralıklarla takip edilir.

- Hastada olası EKG değişikliklerini gözlemlemek için monitörize edilir.

- Hasta ve ailesine potasyumdan zengin gıdalardan kaçınması konusunda eğitim verilir.

- Hastada sıvı volüm fazlalığı varsa ve diüretik kullanılması gerekiyorsa hekimle görüşülüp potasyum tutucu diüretiklerden kaçınılır.

- Potasyumun hücre içine girişini kolaylaştırmak için hekim orderı doğrultusunda hastaya tamponize mayi (Kristalize insülin+ $\% 5$ ya da $\% 10$ dekstroz içeren mayi) takılır.

- Tamponize mayi infüzyonu sırasinda hasta hipoglisemi belirti ve bulguları yönünden takip edilir.

- Tamponize mayi infüzyonu öncesi, sırası ve sonrasında hastanın düzenli olarak plazma glukoz düzeyi ölçülür ve kaydedilir.

Hemşirelik Tanısı 2. Spontan ya da antikanser tedaviye yanıt olarak tümör hücrelerinin lizisine sekonder serum fosfat düzeyinin yükselmesine bağgl Hiperfosfatemi

Amaç: Hastada serum fosfat düzeyinin normal aralıklarda olması

Hemşirelik Girişimleri:

- Hastanın yaşamsal bulguları takip edilir.

- Hasta hiperfosfatemi belirti ve bulguları (anüri/oligüri, azotemi belirti ve bulguları, hipokalsemi) yönünden takip edilir.

- Hastanın serum fosfat değeri düzenli aralıklarla takip edilir.

- Hastanın aldığı çıkardığı sıvı takibi takibi yapilir.
- Hasta ve ailesine fosfattan zengin gidalardan kaçınması konusunda eğitim verilir.

- Hekim istemi doğrultusunda oral fosfat bağlayıcı ilaçlar uygulanır.

- Oral fosfat bağlayıcı ilaçların etkinliğinin sağlanabilmesi için yemekle birlikte ya da yemekten hemen sonra verilir.

- Hekim istemi doğrultusunda rasburikaz uygulanır.

- Rasburikaz alan hastanın hidrasyon durumunu değerlendirir.

- Kalsiyum fosfat bileşikleri renal tübüllerde birikerek renal fonksiyonları etkileyeceği için hastanın üre, kreatinin, ürik asit gibi böbrek fonksiyon testlerini takip eder.

Hemşirelik Tanısı 3. Hiperfosfatemiye sekonder kalsiyum fosfat bileşiklerinin oluşması nedeniyle serum kalsiyum düzeyinin düşmesine bağlı Hipokalsemi

Amaç: Hastada hipokalsemi belirti ve bulgularının gerilemesi

\section{Hemşirelik Girişimleri:}

- Hastanın yaşamsal bulguları takip edilir.

- Hasta hipokalsemi belirti ve bulguları (tetani, nöbet, parestezi, deliryum, ventriküler ritm bozukluğu vb.) yönünden takip edilir.

- Hastanın serum kalsiyum düzeyi düzenli aralıklarla takip edilir.

- Hastaya hekim istemi doğrultusunda intravenöz (IV) kalsiyum glukonat infüzyonu yapilır.

- Kalsiyum glukonat infüzyonunun yavaş yapılması ve ilacın uygun mayi ile dilüe edilmesine özen gösterilir.

- Kalsiyum glukonat infüzyonunun yapılacağı damar yolunun açıklığı kontrol edilir ve infüzyon sirasında damar yolu ekstravazasyon açısından izlenir.

- Hasta olası EKG değişikliklerini gözlemlemek için monitörize edilir.

Hemşirelik Tanısı 4. Hiperürisemi, kalsiyum fosfatın renal tübüllerde çökmesi ve renal fonksiyonların bozulmasına bağlı Stvı Volüm Fazlalı̆̆

Amaç: Hastada sıvı volüm dengesinin sağlanması Hemşirelik Girişimleri:

- Hastanın yaşamsal bulguları düzenli aralıklarla takip edilir.

- Hasta monitörize edilir.

- Hastanın aldığı çıkardığı sıvı takibi yapılır.

- Hasta her gün aynı kiyafetlerle tartılır ve kilosu kaydedilir.

- Hastada sıvı volüm fazlalığını gösteren boyunda venöz dolgunluk, periferik ödem, kan basıncı yüksekliği vb. takip edilir. 
- Hiperürisemiyi kontrol altına almak için hekim istemi doğrultusunda allopurinol ya da rasburikaz uygulanır.

- Rasburikaz uygulanacaksa hastanın IV hidrasyonu dikkatli bir şekilde uygulanır.

- Hiperfosfatemiye yönelik hemşirelik girişimleri uygulanır.

- Hastanın serum üre, ürik asit, kreatinin değerleri takip edilir.

- Hastaya böbrek koruyucu diyet (proteinden k1sitli) önerilir.

- Hastaya diyaliz uygulanacaksa işlem öncesi, siras1 ve sonras1 hasta hazırlanır ve komlikasyonlar yönünden izlenir.

Hemşirelik Tanısı 5. Spontan ya da antikanser tedaviye yanıt olarak tümör hücrelerinin lizisine sekonder laktik asit oluşumu nedeniyle asidoz gelişmesine bağlı Etkisiz Solunum Örüntüsü

Amaç: Hastanın solunum fonksiyonunu etkili bir şekilde yerine getirmesi

\section{Hemşirelik Girişimleri:}

- Hastanın solunum hızı, ritmi, derinliği değerlendirilir.

- Hasta solunum güçlüğü belirti ve bulguları (dispne, burun kanadi solunumu vb.) yönünden takip edilir.

- Hastanın akciğer sesleri dinlenerek anormal ses varsa kaydedilir.

- Hastanın satürasyonu düzenli aralıklarla takip edilir, gerekirse oksijen verilir.

- Hastanın kan gazı değerleri $\left(\mathrm{PO}_{2}, \mathrm{PCO}_{2}\right.$, laktik asit, $\mathrm{HCO}_{3}$ ) takip edilir.

- Hastaya hekim istemi doğrultusunda bronkodilatatör ilaçları uygulanır.

- Hastanın solunumu daha rahat yapabilmesi için semi fowler pozisyon verilir.

İlaç, ürik asit seviyelerini düşürmek için hızlı bir şekilde çalışır ve serum potasyum, fosfat, kalsiyum ve kreatinin seviyelerini kontrol etmeye yardıme olmaktadır (Mackiewicz, 2012; Beth McGraw, 2008). Rasburikaz alan bir kanser hastasında ürik asit analizi için alınan örnekler laboratuvara güvenli bir şekilde gönderilmelidir (Sarno, 2013). Doğru ürik asit sonuçlarını elde edebilmek için kan örneği alındıktan sonra, nakil sırasında ve laboratuvarda işlenmeyi beklerken örnek buz üzerine yerleştirilmelidir (Held-Warmkessel, 2010; Sarno, 2013).

\section{Komplikasyonların Önlenmesi}

Rasburikaz alacak hastalarda allopurinol kesilmeli ve iki ilaç asla birlikte kullanılmamalıdır. Rasburikaz tedavisi uygulamadan önce hastanın hidrasyonunun sağlanmış olması önemlidir (TahoTammy ve Winokur, 2019).
Aşırı duyarlılık reaksiyonu riski nedeniyle rasburikaz tedavisi başlamadan önce acil ilaçların (oksijen, epinefrin, kortiko steroidler ve difenhidramin gibi) hazır olduğundan emin olunmalidır (Sarno, 2013; Taho-Tammy ve Winokur, 2019,). Rasburikaz tedavisi boyunca yaşamsal bulgular alınmalı ve ilaç uygulaması boyunca hasta yakından izlenmelidir (Coiffier ve Riouffol, 2007). Aşırı duyarlılık reaksiyonlarının belirtileri arasında ürtiker, bronkospazm, göğüs rahatsızlığı, nefes darlığı, hipoksi ve hipotansiyon bulunmaktadır (Hochberg ve Cairo, 2008). Rasburikaz infüzyonunu aşırı duyarlılık reaksiyonunun ilk belirtisinde infüzyon durdurularak hastanın hava yolu, solunum, dolaşımı değerlendirilmeli ve yaşamsal bulgular alınarak hekime bilgi verilip order edildiği şeklide uygun tedavi uygulanmalıdır (Coiffier ve Riouffol, 2007; Hochberg ve Cairo, 2008).

Baş ağrısı, kızarıklık, ateş ve kusma, rasburikaz ile ilişkili en yaygın yan etkilerdir (Coiffier ve Riouffol, 2007). Tekrarlanan dozlarda ek advers reaksiyonlar arasında karaciğer enzimlerinde artış, ürtiker, kaşıntı, kızarma, nefes darlığı ve göğüs ve sırt ağrısı bulunmaktadır (Hochberg ve Cairo, 2008). Buna ek olarak rasburikaz, şiddetli hemoliz riski nedeniyle glukoz-6-fosfat dehidrogenaz eksikliği olan hastalara asla uygulanmamalıdır. Onkoloji hemşiresi ilaç yan etkilerinin farkında olmalıdır (Held-Warmkessel, 2010).

Hiperkalemiye yönelik girişimler arasında; Sodyum polistiren sülfonat, IV diüretikler, IV glukoz veya insülin infüzyonları, IV kalsiyum glukonat veya diyaliz uygulaması yer almaktadır (Beth McGraw, 2008). Hiperfosfatemi ve hipokalsemiye yönelik olarak yapılacak girişimler arasında; IV \% 10 kalsiyum glukonat infüzyonu, alüminyum hidroksit gibi oral fosfat bağlayıcılar, fosfor alımının diyetle kısitlanması veya diyaliz yer almaktadır (Mirrakhimov, Voore, Khan ve Ali, 2015Zafrani, Canet ve Darmon, 2019). Hiperürisemiye yönelik olarak; allopurinol, rasburikaz ve diyaliz yer almaktadır (Mirrakhimov, Voore, Khan ve Ali, 2015). Siv1-elektrolit dengesizliklerine yönelik olarak kanser hastasının monitörize edilmesi, yaşamsal bulgularının ve laboratuvar değerlerinin takip edilmesi, aldığ çıkardığı Sıv1 ve kilo takibinin yapılması önemlidir (Beth McGraw, 2008).

\section{Sonuç ve Öneriler}

TLS kanser hastalarında gelişen multidisipliner bir anlayışla bakım verilmesi gereken bir sendromdur. TLS iyi yönetilmediği takdirde birçok 
komplikasyona ve ölüme neden olan önemli bir onkolojik acildir. TLS'nin hemşirelik yönetiminde; spontan ya da antikanser tedavisine yanıt olarak TLS gelişme riski yüksek hastaların risk grubuna göre sınıflandırılması, önleyici girişimlerde bulunulması, beslenme, boşaltım,

komplikasyonların önlenmesi, ilaç yan etki takibi önemlidir.

Araştırmanın Etik Yönü/ $\begin{gathered}\text { Ethics Committe } \\ \text { spüresince kullanıla }\end{gathered}$
kaynaklar kaynakça bölümünde gösterilmiştir.
Hakem/Peer-review: Dış hakem değerlendirmesi.
Yazar Katkısı/Author Contributions: Fikir/kavram:
Fikir/kavram: NÖ, FA; Tasarım: NÖ, FA; Kaynak
tarama: NÖ, FA; Makalenin Yazımı: NÖ, FA; Eleştire
inceleme: NÖ, FA.
Çıkar çatışması/Conflict of interest: Çalışmad
herhangi bir çıar çatışması söz konusu değildir.
Finansal Destek/Financial Disclosure: Bu çalışm
herhangi bir kurum ya da kuruluş tarafindan
desteklenmemiştir.
- Çalışma Literatüre Ne Kattı?
TLS'de tedavi ve bakıma ilişkin bilgi verilmiştir.
TLS'de hemşirelik bakımının önemine dikkat
çekmektedir.
Onkoloji hemşirelerinin konuyla ilgili bilgi
düzeylerinin artmasını sağlayarak farkındalık
oluşturmaktadır.

\section{Kaynaklar}

Adeyinka A, Bashir K. (2019). Tumor lysis syndrome. In StatPearls [Internet]. StatPearls Publishing. https://www.ncbi.nlm.nih.gov/books/NBK518985/. Erişim tarihi: 12.07.2020.

Alakel N, Middeke JM, Schetelig J, Bornhäuser M. (2017). Prevention and treatment of tumor lysis syndrome, and the efficacy and role of rasburicase. OncoTargets and Therapy, 10, 597-605.

Belay Y, Yirdaw K, Enawgaw B. (2017). Tumor lysis syndrome in patients with hematological malignancies. Journal of Oncology, 17; 9684909.

Beth McGraw RN. (2008). At an increased risk: tumor lysis syndrome. Clinical Journal of Oncology Nursing, 12(4), 563-565.

Pace A.F., (2015). Electrolyte 1mbalances, syndrome of inappropriate antidiuretic hormone, and tumor lysis synedrome. Brown CG. (Ed). A Guide to Oncology Symptom Management. Pittsburg: ONS, p. 319-68.

Cairo MS, Bishop M. (2004). Tumour lysis syndrome: new therapeutic strategies and classification. British Journal of Hematology, 127(1), 3-11.
Criscuolo M, Fianchi L, Dragonetti G, Pagano L. (2016). Tumor lysis syndrome: review of pathogenesis, risk factors and management of a medical emergency. Expert Review of Hematology, 9(2), 197-208.

Coiffier B, Riouffol C. (2007). Management of tumor lysis syndrome in adults. Expert Review of Anticancer Therapy, 7(2), 233-239.

Darmon M, Guichard I, Vincent F, Schlemmer B, Azoulay É. (2010). Prognostic significance of acute renal injury in acute tumor lysis syndrome. Leukemia \& Lymphoma, 51(2), 221-227.

Edeani A, Shirali A. (2017). Chapter 4: Tumor lysis syndrome. Onco-Nephrology Curriculum, Mark A. Perazella editor. Washington, DC: American Society of Nephrology, p.1-8.

Held-Warmkessel J. (2010). How to prevent and manage tumor lysis syndrome. Nursing 2019, 40(2), 26-31.

Hüzmeli, C. (2019). Assessment of tumor lysis syndrome cases. Cumhuriyet T1p Dergisi, 41(1), 28-33.

Hochberg J, Cairo MS. (2008). Rasburicase: future directions in tumor lysis management. Expert Opinion on Biological Therapy, 8(10), 1595-1604.

Garimella PS, Balakrishnan P, Ammakkanavar NR, Patel S, Patel A, Konstantinidis I, Nadkarni, GN. (2017). Impact of dialysis requirement on outcomes in tumor lysis syndrome. Nephrology, 22(1), 85-88.

Gönderen Çakmak H.S. (2020). Tümör lizis sendromu. Kapucu S., Kutlutürkan S. (Editörler). Hemşirelik Öğrencilerine Yönelik Onkoloji Hemşireliği. Ankara: Hipokrat yayınc1lık, s.447-453.

Kaplow R, Iyere K. (2016). Recognizing and preventing tumor lysis syndrome. Nursing 2019, 46(11), 26-32.

Jones GL, Will A, Jackson GH, Webb NJ, Rule S, British Committee for Standards in Haematology. (2015). Guidelines for the management of tumour lysis syndrome in adults and children with haematological malignancies on behalf of the British Committee for Standards in Haematology. British Journal of Haematology, 169(5), 661-671.

Mackiewicz T. (2012). Prevention of tumor lysis syndrome in an outpatient setting. Clinical Journal of Oncology Nursing, 16(2),189-193.

Mirrakhimov AE, Voore P, Khan M, Ali AM. (2015). Tumor lysis syndrome: a clinical review. World Journal of Critical Care Medicine, 4(2), 130-138.

Puri I, Sharma D, Gunturu KS, Ahmed AA. (2020). Diagnosis and management of tumor lysis syndrome. Journal of Community Hospital Internal Medicine Perspectives, 10(3), 269-272.

Özen AT, Enç N. (2013). Kritik hastalıklarda sıvı elektrolit dengesi değişikliklerinde hemşirenin rolü. Kardiyovasküler Hemşirelik Dergisi, 4(5), 9-13.

Sarno J. (2013). Prevention and management of tumor lysis syndrome in adults with malignancy. Journal of the Advanced Practitioner in Oncology, 4(2), 101-106.

Sleutel MR, Brown W, Wells JN. (2016). Preventing Tumor Lysis Syndrome: Two Case Studies of 
Unexpected Outcomes. Clinical Journal of Oncology Nursing, 20(2), 195-200.

Strauss PZ, Hamlin SK, Dang J. (2017). Tumor lysis syndrome: a unique solute disturbance. Nursing Clinics, 52(2), 309-320.

Taho-Tammy T, Winokur EJ. (2019). Tumor Lysis Syndrome: A Practical Guide for Nurse Practitioners. The Journal for Nurse Practitioners, 15(9), 636-639.

Zafrani L, Canet E, Darmon M. (2019). Understanding tumor lysis syndrome. Intensive Care Medicine, 45(11), 1608-1611.

Wilson FP, Berns JS. (2014). Tumor lysis syndrome: new challenges and recent advances. Advances in Chronic Kidney Disease, 21(1), 18-26.

Williams SM, Killeen AA. (2019). Tumor lysis syndrome. Archives of Pathology \& Laboratory Medicine, 143(3), 386-393.British Thoracic Society Nebulizer Project Group (1997). Current best practice for nebuliser treatment. Thorax, 52(2), 1-3. 